\title{
Integrating societal perspectives and values for improved stewardship of a coastal ecosystem engineer
}

\author{
$\underline{\text { Steven B. Scyphers }}^{1,2,3}, \underline{\text { Steven Picou }}^{4}$, $\underline{\text { Robert D. Brumbaugh }}^{5}$ and Sean P. Powers $^{1,2}$
}

\begin{abstract}
Oyster reefs provide coastal societies with a vast array of ecosystem services, but are also destructively harvested as an economically and culturally important fishery resource, exemplifying a complex social-ecological system (SES). Historically, societal demand for oysters has led to destructive and unsustainable levels of harvest, which coupled with multiple other stressors has placed oyster reefs among the most globally imperiled coastal habitats. However, more recent studies have demonstrated that large-scale restoration is possible and that healthy oyster populations can be sustained with effective governance and stewardship. However, both of these require significant societal support or financial investment. In our study, we explored relationships among how coastal societies (1) perceive and value oyster ecosystem services, (2) recognize and define problems associated with oyster decline, and (3) perceive or support stewardship initiatives. We specifically focused on the SES of eastern oysters (Crassostrea virginica) and coastal societies in the northern Gulf of Mexico, a region identified as offering among the last and best opportunities to sustainably balance conservation objectives with a wild fishery. We found that, in addition to harvest-related benefits, oysters were highly valued for providing habitat, mitigating shoreline erosion, and improving water quality or clarity. Our results also showed that although most respondents recognized that oyster populations have declined, many respondents characterized the problem differently than most scientific literature does. Among a variety of initiatives for enhancing sustainability, spawning sanctuaries and reef restoration were well supported in all states, but support for harvest reductions was less consistent. Our study suggests that public support for maintaining both harvest and ecosystem services exists at societal levels and that enhancing public awareness regarding the extent and causes of oyster decline could garner additional support for stewardship initiatives. Collectively, the societal, economic, and biophysical complexities of the northern Gulf of Mexico oyster SES illustrate the need and public support for developing more comprehensive management schemes for exploited ecosystem engineers.
\end{abstract}

Key Words: common pool resource; Crassostrea virginica; ecosystem-based management; ecosystem services; marine protected areas; restoration; spawning sanctuaries

\section{INTRODUCTION}

Species that form coastal habitats such as salt marshes, mangroves, seagrasses, coral reefs, and oyster reefs have been described as "ecosystem engineers" because of their transforming influence on the surrounding biophysical environment (Jones et al. 1994). These same habitats also provide human societies with a diverse suite of ecosystem services including shoreline stabilization, nutrient cycling, carbon sequestration, food, and recreation (e.g., Millennium Ecosystem Assessment 2005, Naidoo et al. 2008). However, many coastal habitats have experienced dramatic declines and continue to face natural and anthropogenic stressors including pollution, storms, and climate change (e.g., Jackson 2001, Pandolfi et al. 2003, Halpern et al. 2008). Although the potential for recovering lost ecosystem functions and services exists if natural habitats are sufficiently protected and restored (Lotze et al. 2006), these investments are often costly, require societal and stakeholder support, and involve trade-offs. Hence, coastal habitats and human societies form dynamic socialecological systems (SESs), linked by the many ecosystem services that have supported civilizations for millennia and by the positive or negative impacts of human decisions (Fig. 1; e.g., Vitousek et al. 1997, Jackson et al. 2001, Chapin et al. 2009).

Ecosystem engineers that are exploited for fisheries present an interesting, yet difficult, dilemma for conservationists and resource managers because of the need to balance their ecosystem services with the potential for direct economic gains via harvest (Coleman and Williams 2002, Carranza et al. 2009). For instance,
Fig. 1. Illustration of a coupled social-ecological system involving stressors, stewardship, oyster reef health and ecosystem services. Our study design focused on measuring relationships between societal values and beliefs on ecosystem services (a), problem definition and recognition (b-c), and perceived effectiveness and support for alternatives and stewardship initiatives (d-f).

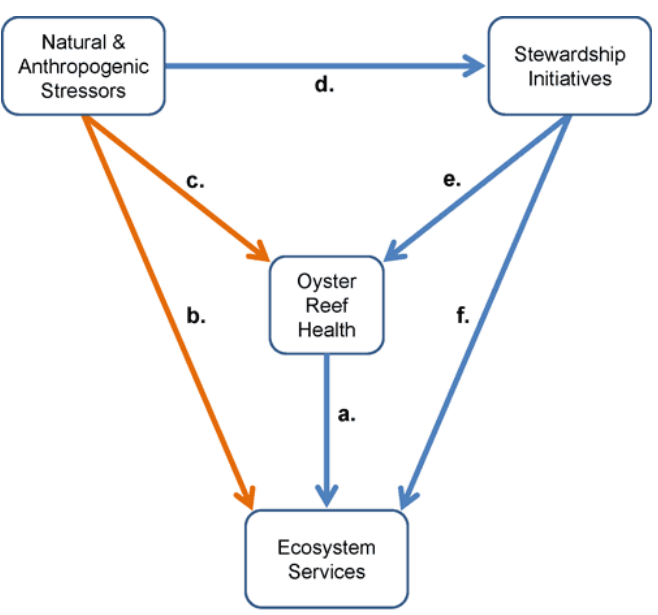

${ }^{1}$ University of South Alabama, ${ }^{2}$ Dauphin Island Sea Lab, ${ }^{3}$ Northeastern University, ${ }^{4}$ Coastal Resource and Resiliency Center University of South Alabama, ${ }^{5}$ The Nature Conservancy 
the ecosystem services provided by oyster reefs include essential habitat and foraging grounds for numerous species of fishes and mobile invertebrates (e.g., Coen et al. 1999, Peterson et al. 2003, Grabowski et al. 2005, Humphries et al. 2011); erosion control and coastal protection (Meyer et al. 1997, Piazza et al. 2005, Scyphers et al. 2011); and water filtration, benthic-pelagic coupling, and enhanced denitrification (e.g., Newell 2004, Piehler and Smyth 2011, Beseres et al. 2013). At the same time, few fisheries have been as culturally diverse and symbolic as the oyster fishery (Dyer and Leard 1994, Kurlansky 2007). Oysters are currently, or have historically been, harvested extensively for food, fertilizer, and building materials, and are strongly linked to cultural heritage in coastal communities (Dyer and Leard 1994). Unfortunately, because of destructive and excessive harvesting, disease, and predation, oyster reefs are now one of the most globally imperiled estuarine habitats (Kirby 2004, Beck et al. 2011). Stewardship strategies such as habitat restoration and spawning sanctuaries have proven beneficial when harvest occurs at sustainable levels (Soniat et al. 2012a) or is restricted (Powers et al. 2009, Schulte et al. 2009), but all of these actions require substantial financial or societal support.

Enhancing the sustainability of a complex SES often requires understanding and navigating the values and perspectives of diverse stakeholders (e.g., Schultz et al. 2005, Ostrom 2009, Heberlein 2012, Menzel and Buchecker 2013). To contextualize the complex dynamics between communities and exploited resources such as fisheries, many studies have focused on understanding how social factors such as resource dependency can influence the behaviors and outcomes of individuals and communities (Bailey and Pomeroy 1996, Picou and Marshall 2002, Stedman et al. 2004). In coastal regions, scholars have argued that communities may be more or less dependent upon particular resources because of the diversity of economic opportunities, e.g., tourism, maritime industries (Bailey and Pomeroy 1996, Adger 2000), but also that dependency on the overall health of the ecosystem may be great (Adger 2000, Gill and Picou 2001). Resource and environmental dependency may also transcend mere economic vitality and contribute to an overall cultural identity in communities (Picou and Marshall 2002). Hence, understanding societal values, perspectives, and characteristics such as environmental dependency is important for predicting and enhancing support for ecosystem management and stewardship initiatives (Adger 2000), especially when they are costly, require broad participation or large investments, or involve explicit trade-offs (Heberlein 2012, Rudel 2013, Tidball and Stedman 2013, Zander 2013).

Considering the importance of oysters as a fisheries resource, the diverse ecosystem services provided by reefs, and the multitude of natural and anthropogenic stressors responsible for population declines, it seems likely that achieving long-term sustainability within this SES will require societal support for alternative management strategies or continued investment in stewardship initiatives. To explore the social dynamics within this complex SES, we studied the relationships among values and beliefs, problem recognition and definition, and support for alternatives and initiatives across three states in the northern Gulf of Mexico (GOM). Our study consisted of two independent surveys of coastal residents, both of which measured societal beliefs and values regarding the importance of oyster ecosystem services, current status and trajectory of oyster populations, major causes of oyster decline, and support for or perceived effectiveness of stewardship initiatives.

We used the results of these two surveys and drew from resource dependency theory to explore an overarching hypothesis that values, perspectives, and environmental dependence can influence support for or perspectives on ecosystem stewardship in coastal communities. We predicted that individuals with greater environmental dependence would be more aware of oyster ecosystem services, population declines, and stressors than lessdependent respondents. We also predicted that individuals having greater awareness of oyster ecosystem services, population declines, and stressors would be more supportive of or have more favorable perspectives on ecosystem stewardship than less-aware respondents.

\section{METHODS}

\section{Study area}

The northern GOM is among the few ecoregions where oysters remain in great enough abundance to support substantial fisheries (Beck et al. 2011), although complex biophysical, social, and management dynamics have contributed to divergent fishery and population trajectories among different states (Fig. 2). The physical and ecological factors that affect oyster populations in the region have been extensively studied (e.g., Piazza et al. 2005, Stunz et al. 2010, Humphries et al. 2011, Beseres et al. 2013), but very few studies have specifically considered societal or stakeholder influences on sustainability (La Peyre et al. 2012).

Fig. 2. Historical harvest of oysters (Crassostrea virginica) in Alabama, Louisiana, and Texas according to the National Marine Fisheries Service landings database (a), and map of the northern Gulf of Mexico with black squares surrounding the study regions (b).

a.

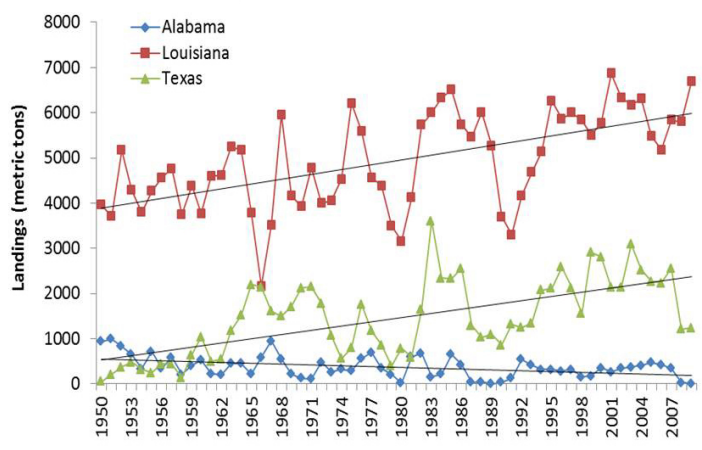

Year

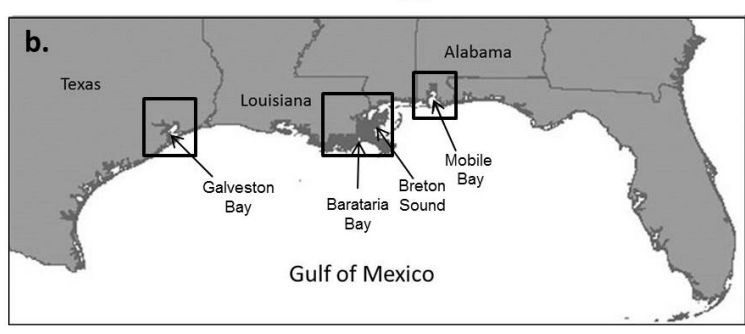


The Alabama, Louisiana, and Texas coastal communities included in this study were in close proximity to bays and coastal waters recognized to have substantial oyster productivity and reef habitat (Fig. 2; Zu Ermgassen et al. 2012). Specifically, our surveys focused on the coastal regions surrounding Mobile Bay (Alabama), Barataria Bay and Breton Sound (Louisiana), and Galveston Bay (Texas). In a recent study of historical oyster reef coverage and biomass levels, Mobile Bay, Alabama, was highlighted as currently supporting reefs that were more than $90 \%$ of their historical size, but with only $20 \%$ of their historical biomass ( 100 years ago; Zu Ermgassen et al. 2012). In Louisiana, Barataria Bay was found to currently contain $45 \%$ as much oyster biomass as its historical baseline, but the Breton and Chandeleur sounds were said to support reefs more than $80 \%$ as large in footprint with $119 \%$ as much biomass as there was historically. Galveston Bay, Texas, was documented as containing reefs that were $83 \%$ of their historical size but only supporting $7 \%$ as much oyster biomass. Cumulatively, these three states account for more than $80 \%$ of oyster landings for the GOM and $40 \%$ of all U.S. oyster landings. However, historical and recent trajectories of oyster landings among the states have been much more variable (Fig. 2).

Alabama, Louisiana, and Texas also provide contrasting examples of management approaches and harvesting technologies (Dyer and Leard 1994, Dugas et al. 1997, National Marine Fisheries Service 2009). In Alabama, the oyster fishery and associated fishing industries have been described as open access, where participation in the fishery is relatively unrestricted (Dyer and Leard 1994). Historically, the Alabama oyster fishery has been conducted primarily on public oyster beds using hand tongs (reviewed in Dugas et al. 1997). The fishing economy of coastal Alabama is relatively diverse with processing of shrimp, crabs, and finfish, making it somewhat more resilient than communities solely or heavily dependent on oyster harvest alone (Dyer and Leard 1994).

In contrast, the oyster fishery of Louisiana relies upon harvest from both publicly accessible and privately leased bottoms and has been categorized as largely closed because of its high level of privatization (Dyer and Leard 1994). The leasing system, which has been shown to promote territoriality and ownership attitudes that may lead to sustainable harvesting behaviors and prevent illegal activities (Beck et al. 2004), is built upon a tradition of folk management dating back to the 1850s (Dyer and Leard 1994). For more than a century, the most common method of harvest in Louisiana has been the mechanical dredge towed alongside or behind a fishing vessel. Dredging has been generally viewed by harvesters as a more efficient oyster fishing technique than hand tonging (Dugas et al. 1997), but dredging is more physically disruptive and can degrade the integrity of the reef matrix and associated faunal community (Lenihan and Peterson 2004). Historically, the Texas oyster fishery has been characterized by landings from a combination of public $(\sim 90 \%)$ and privatized or leased $(\sim 10 \%)$ bottom, the majority of which are found in Galveston Bay (Dugas et al. 1997). Similar to Louisiana, the primary mechanism of harvesting has been dredging (Ward and Weeks 1994).

\section{Survey instruments and data collection}

The two separate surveys presented in this study were conducted across the three states of Alabama, Louisiana, and Texas between 2009 and 2010, providing a near-synoptic assessment of coastal residents' knowledge and perspectives. Although the two surveys differed somewhat in their format, all were developed with local expert involvement, e.g., academic scientists, resource managers, conservation practitioners, and focused on the same four major themes. The random-digit dial surveys were administered by academic or private polling centers, which surveyed randomly selected adults who were at least 18 years old. For all three states, the sample stratification across counties is provided in Appendix 1 .

The Alabama survey was completed by the University of North Florida Polling Lab between September and October 2010, consisted of 64 questions, took approximately 12 to 15 minutes to complete, and had an overall error rate of $\pm 3 \%$ for the complete sample $(n=928)$. The Louisiana $(n=400)$ and Texas $(n=400)$ surveys were conducted in April 2009 by Fairbank, Maslin, Maullin, and Associates, with an overall error rate of $\pm 4.9 \%$ for the complete sample in each state. For both surveys, sampling was conducted until the predetermined sample size was reached. The survey consisted of 28 questions, and each interview was approximately 15 minutes. Both surveys utilized the following independent variables to describe the demographics of the sample: sex, race, age, education, and environmental dependence. In the Alabama survey, environmental dependence was measured as perceived dependence on healthy coastal ecosystems, and respondents who stated either "a great deal" or "a fair amount" were considered dependent. In the Texas and Louisiana survey, environmental dependence was measured as perceived dependence on a healthy fishing economy, and respondents who stated either "very" or "somewhat" were considered dependent.

The synthesis of these independently conducted surveys was approached with caution to minimize potential bias. To assess potential artifacts related to the slightly different wording of survey questions, the instruments were critically assessed by a panel of natural and social scientists and wording differences deemed relevant remain distinct in our results and discussion. It should also be stated that telephone surveys in general have drawbacks, including the general trend of declining use of landline telephones, but they remain a common approach used by social science and public polling researchers under many circumstances (Johnson and Williams 2013).

\section{Analyses}

We used univariate, multivariate, and classification analyses to explore relationships among values and beliefs, problem recognition and definition, support for initiatives, and sociodemographical variables. First, we tested the effect of environmental dependence, i.e., resource dependency theory, on all categorical response variables using Fisher's exact tests. Second, we created representative scales for the Texas and Louisiana data to collectively describe values and beliefs regarding ecosystem services (ecosystem-services scale), problem recognition and definition (major-causes-of-decline scale), and support for initiatives (support-for-initiatives scale) by testing for internal reliability using Cronbach's $\alpha$ (Cronbach 1951). When necessary, poorly contributing items were excluded to achieve $\alpha$ $\geq 0.70$. When split-sample questions were used in the survey, two separate scales were calculated, and the scale with the highest $\alpha \geq$ 0.70 was used for further analyses. For Alabama, the categorical response questions regarding overall environmental health and major cause of decline were used in place of scales. Third, we used regression to identify factors that significantly influenced 
Table 1. Sample descriptions and demographics for the three random-digit dial telephone surveys.

\begin{tabular}{|c|c|c|c|c|}
\hline Demographics & Alabama & & Louisiana & Texas \\
\hline Sample Size & 928 & & 400 & 400 \\
\hline \multicolumn{5}{|l|}{ Gender } \\
\hline Male & $37 \%$ & & $47 \%$ & $47 \%$ \\
\hline Female & $63 \%$ & & $53 \%$ & $53 \%$ \\
\hline \multicolumn{5}{|l|}{ Race } \\
\hline White & $81 \%$ & & $63 \%$ & $60 \%$ \\
\hline Black or African American & $14 \%$ & & $30 \%$ & $18 \%$ \\
\hline Hispanic or Latino ${ }^{\dagger}$ & & & $2 \%$ & $12 \%$ \\
\hline Other & $5 \%$ & & $4 \%$ & $5 \%$ \\
\hline \multicolumn{5}{|l|}{ Education } \\
\hline High School Diploma or Less & $27 \%$ & & $44 \%$ & $23 \%$ \\
\hline Some College & $34 \%$ & & $23 \%$ & $31 \%$ \\
\hline Bachelor's degree or higher & $39 \%$ & & $33 \%$ & $45 \%$ \\
\hline \multicolumn{5}{|l|}{ Household Income } \\
\hline Under $\$ 20 \mathrm{k}$ & $12 \%$ & Under $\$ 30 \mathrm{k}$ & $25 \%$ & $18 \%$ \\
\hline$\$ 20 \mathrm{k}-\$ 60 \mathrm{k}$ & $33 \%$ & $\$ 30 \mathrm{k}-\$ 60 \mathrm{k}$ & $27 \%$ & $19 \%$ \\
\hline$\$ 60 \mathrm{k}-\$ 80 \mathrm{k}$ & $18 \%$ & $\$ 60 \mathrm{k}-\$ 75 \mathrm{k}$ & $10 \%$ & $9 \%$ \\
\hline Over $\$ 80 \mathrm{k}$ & $23 \%$ & Over $\$ 75 \mathrm{k}$ & $17 \%$ & $27 \%$ \\
\hline \multicolumn{5}{|l|}{ Employed } \\
\hline Yes & $52 \%$ & & $52 \%$ & $58 \%$ \\
\hline Environmental Dependence & $38 \%$ & & $29 \%$ & $23 \%$ \\
\hline \multicolumn{5}{|l|}{ 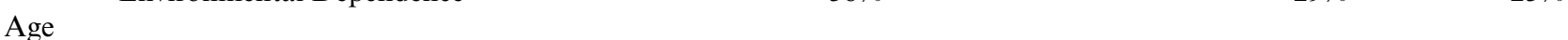 } \\
\hline Mode & $>61$ & & $45-49$ & $55-59$ \\
\hline Survey Year & 2010 & & 2009 & 2009 \\
\hline
\end{tabular}

${ }^{\dagger}$ In the Alabama survey, respondents of any race could indicate Hispanic ethnicity.

${ }^{\ddagger}$ Measured as perceived dependence on healthy coastal ecosystems in the Alabama survey or a healthy fishing economy in Louisiana and Texas.

perceived effectiveness in Alabama or overall support in Texas and Louisiana of alternatives and initiatives. For Alabama, we used a multinomial logistic regression model. For Louisiana and Texas, we used multiple linear regression models. Finally, we used classification and regression tree analyses to identify the most powerful predictors of support for restoration, sanctuaries, and marine protected areas (MPAs). Prior to analyses, ordered response variables were converted, with some consolidation and reverse coding necessary, to Likert scores for the data analysis (Agresti and Finlay 1997), and percent responses were also calculated for clarity. Nonresponses and responses of "do not know" or "do not care" were not considered in analyses. All analyses were conducted using the Statistical Package for the Social Sciences, version 21 (IBM 2012), and statistical significance was considered to be $P \leq 0.05$.

\section{RESULTS}

The two surveys presented in our study included 1728 individuals who represented a broad range of demographic and socioeconomic backgrounds across the three states in the northern GOM (Table 1). The proportion of participants who stated that their occupation depended on healthy coastal waters or fisheries was highest in Alabama and lowest in Texas. Of the Alabama residents who were currently employed, 38\% believed their occupation directly depended on healthy coastal ecosystems. In the other states, more than half of participants stated that they were currently employed; of those, $29 \%$ of Louisianans and $23 \%$ of Texans believed their jobs depended on a healthy fishing economy.

Values and beliefs about ecosystem services

In Alabama, the questions pertaining to values and beliefs regarding ecosystem services focused on the importance of oyster reefs for overall environmental health, habitat for fish and crabs, water clarity, and protection of shoreline marsh habitats. All ecosystem services were recognized and perceived to be important, and the importance of oysters for overall environmental health and mitigating marsh erosion was most recognized (Table 2). The perceived value of oyster reefs for protecting marshes was less valued by environmentally dependent respondents, but the provision of habitat for fish, shrimp, and crabs was more recognized by individuals dependent upon healthy coastal ecosystems.

In Louisiana and Texas, residents were asked about the importance of oyster reefs for maintaining water quality, reducing marsh erosion, coastal culture, shelter for marine life, industry jobs, habitat for fish and crabs, foraging grounds for fish, and fertilizer and building supplies. In Louisiana, the ecological functions and services involving foraging and breeding grounds, water quality, shoreline erosion, and fishing industry jobs were considered very important by more than $80 \%$ of participants (Table 3). Habitat and refuge were perceived as more important by environmentally dependent respondents, but perceptions of 
Table 2. Survey response descriptives and results of Fisher's Exact Tests (FET) on environmental dependence for Alabama.

\begin{tabular}{|c|c|c|c|c|}
\hline \multirow[b]{2}{*}{ Alabama } & \multirow[b]{2}{*}{$\%$} & \multicolumn{3}{|c|}{ Environmental Dependence } \\
\hline & & $n$ & FET & $\mathrm{P}$ \\
\hline \multicolumn{5}{|l|}{ Values \& Beliefs } \\
\hline \multicolumn{5}{|l|}{ Ecosystem Services ${ }^{\dagger}$} \\
\hline Overall Ecosystem Health & $42^{\ddagger}$ & 424 & 2.41 & 0.518 \\
\hline Water Clarity & $23^{t}$ & 403 & 1.03 & 0.795 \\
\hline Shoreline Protection - Hurricanes & $39^{\S}$ & 406 & 5.60 & 0.131 \\
\hline Shoreline Protection - Marsh Erosion & $44^{\S}$ & 406 & 11.99 & $0.007 * *$ \\
\hline Habitat & $39^{*}$ & 417 & 11.84 & $0.005^{* *}$ \\
\hline \multicolumn{5}{|l|}{ Problem Definition \& Recognition } \\
\hline Historical Best Condition & & 411 & 0.743 & 0.952 \\
\hline Present Day & 3 & & & \\
\hline 5 Years Ago & 20 & & & \\
\hline 10 Years Ago & 19 & & & \\
\hline 25 Years Ago & 28 & & & \\
\hline 50 or More Years Ago & 30 & & & \\
\hline Cause of Most Decline & & 424 & 5.01 & 0.416 \\
\hline Predation & 3 & & & \\
\hline Hurricanes & 11 & & & \\
\hline Pollution / Poor Water Quality & 61 & & & \\
\hline Overharvest / Ineffective Management & 7 & & & \\
\hline Other & 18 & & & \\
\hline \multicolumn{5}{|l|}{ Alternatives \& Initiatives } \\
\hline Perceived Most Effective Initiative & & 419 & 1.88 & 0.767 \\
\hline Reduced Harvest & 8 & & & \\
\hline Stricter Sewage Spill Fines & 37 & & & \\
\hline Restoration & 22 & & & \\
\hline Spawning Sanctuaries & 33 & & & \\
\hline
\end{tabular}

${ }^{\dagger}$ Individual ecosystem services were posed as separate questions, but because response type varied by question, no cumulative scale was created.

"Shown value is \% Strongly Agree.

${ }^{\S}$ Shown value is $\%$ Very Important.

$* P \leq 0.05$, ** $P \leq 0.01$.

all other services were consistent across groups. For Louisiana, the ecosystem-services scale with the highest $\alpha$ value included the services related to water quality, shoreline erosion, habitat and refuge, food and culture, and industry jobs (Table $3 ; \alpha=0.72$ ). In Texas, water quality, habitat, breeding and foraging grounds, and industry jobs were considered very important by at least $80 \%$ of participants, regardless of environmental dependence (Table 4). The ecosystem-services scale for Texas included water quality, shoreline erosion, habitat and refuge, food and culture, industry jobs, and fertilizer and materials (Table 4 ; $\alpha=0.76$ ).

\section{Problem recognition and definition}

Surveys across all three states found very few participants who believed oyster reefs were currently in excellent condition or their best condition in recent history, but the extent and timing of inferred declines were less clear. In Alabama, perceptions displayed substantial heterogeneity: more than $40 \%$ of respondents believed oyster reefs had been in their best condition within the past ten years, but more than half believed oyster reefs had not been in their best condition in at least 25 years (Table 2). In Louisiana, $31 \%$ of respondents rated oyster populations as "pretty good" or better and only $12 \%$ responded "poor" or "failing" (Table 3). However, 39\% believed that oyster populations in the region were in decline. In Texas, $22 \%$ of respondents rated oyster populations as "pretty good" or better, whereas $30 \%$ responded "poor" or "failing," and 74\% of respondents believed that oyster population levels in nearby waters were in decline (Table 4). Neither perceived current status nor trajectory was affected by environmental dependence in Louisiana or Texas (Tables 3 and 4).

Poor water quality and pollution were perceived as the most damaging cause of decline across all three states. In Alabama, $61 \%$ of respondents indicated that water quality was responsible for the most damage, whereas hurricanes and other developmentrelated factors accounted for $11 \%$ to $18 \%$ (Table 2 ). Ineffective management and natural oyster predators were perceived as the most damaging stressor by only $3 \%$ to $7 \%$ of respondents. In Louisiana, water pollution and hurricanes were perceived to be major causes of oyster decline by at least $70 \%$ of those surveyed, whereas parasites and disease, shell dredging, and overharvest were considered major problems among at least half of the respondents (Table 3). The perceived impact of overharvesting on Louisiana oyster reefs was of greater concern among 
Table 3. Scale descriptives and results of Fisher's Exact Tests (FET) on environmental dependence for Louisiana.

\begin{tabular}{|c|c|c|c|c|c|c|c|c|c|}
\hline \multirow[b]{2}{*}{ Louisiana } & \multirow[b]{2}{*}{$\%$} & \multicolumn{3}{|c|}{$\begin{array}{c}\text { Environmental } \\
\text { Dependence }\end{array}$} & \multirow[b]{2}{*}{$\mathrm{n}$} & \multicolumn{4}{|c|}{$\begin{array}{c}\text { Scale } \\
\text { Descriptives }\end{array}$} \\
\hline & & $\mathrm{n}$ & FET & $\mathrm{P}$ & & Mean & $\mathrm{SD}$ & $\alpha$ & $\Delta \alpha$ \\
\hline \multicolumn{10}{|l|}{ Values \& Beliefs } \\
\hline Ecosystem Services $^{\dagger}$ & (Very Important) & & & & 178 & & & 0.72 & \\
\hline Water Quality & 87 & 182 & 1.46 & 0.701 & & 2.91 & 0.31 & & 0.68 \\
\hline Shoreline Erosion & 85 & 181 & 3.32 & 0.309 & & 2.86 & 0.39 & & 0.68 \\
\hline Habitat and Refuge & 78 & $90^{\ddagger}$ & 7.79 & $0.036^{*}$ & & 2.81 & 0.45 & & 0.66 \\
\hline Food and Culture & 78 & $91^{\ddagger}$ & 3.73 & 0.271 & & 2.81 & 0.44 & & 0.66 \\
\hline Fishing Industry Jobs & 82 & 182 & 3.32 & 0.323 & & 2.82 & 0.41 & & 0.67 \\
\hline Breeding Grounds & 88 & $91^{\ddagger}$ & 4.37 & 0.179 & & & & & \\
\hline Fish Foraging Grounds & 84 & $91^{\ddagger}$ & 3.53 & 0.293 & & & & & \\
\hline Fertilizer and Materials & 56 & 159 & 6.87 & 0.075 & & & & & \\
\hline \multicolumn{10}{|l|}{ Problem Definition \& Recognition } \\
\hline Current Condition & & 135 & 3.78 & 0.42 & & & & & \\
\hline Pretty Good or Better & 31 & & & & & & & & \\
\hline Poor or Failing & 12 & & & & & & & & \\
\hline Trajectory & & 141 & 1.35 & 0.89 & & & & & \\
\hline Increasing & 9 & & & & & & & & \\
\hline Decreasing & 39 & & & & & & & & \\
\hline Causes of Decline† & (Major Cause) & & & & 262 & & & 0.75 & \\
\hline Water pollution & 72 & 180 & 0.97 & 0.697 & & 2.65 & 0.58 & & 0.74 \\
\hline Hurricanes & 70 & 184 & 3.34 & 0.185 & & 2.63 & 0.60 & & 0.74 \\
\hline Overharvesting & 50 & 169 & 7.06 & $0.029 *$ & & 2.34 & 0.71 & & 0.72 \\
\hline Parasites and diseases & 56 & 171 & 3.48 & 0.177 & & 2.47 & 0.63 & & 0.73 \\
\hline Shell dredging & 50 & 152 & 3.90 & 0.142 & & 2.38 & 0.66 & & 0.71 \\
\hline Increased salinity & 44 & 166 & 5.16 & 0.068 & & 2.29 & 0.73 & & 0.72 \\
\hline Climate change & 40 & 178 & 5.38 & 0.068 & & 2.19 & 0.77 & & 0.73 \\
\hline Freshwater inflows & 44 & 162 & 1.56 & 0.500 & & 2.32 & 0.69 & & 0.72 \\
\hline Predation & 22 & 177 & 0.69 & 1.000 & & 1.99 & 0.71 & & 0.74 \\
\hline \multicolumn{10}{|l|}{ Alternatives \& Initiatives } \\
\hline Support for Initiatives ${ }^{\dagger}$ & (Strongly Support) & & & & 353 & & & 0.79 & \\
\hline Spawning Sanctuaries & 58 & $92^{\ddagger}$ & 1.50 & 0.710 & & 3.45 & 0.75 & & 0.75 \\
\hline $\begin{array}{l}\text { Shell Planting / } \\
\text { Restoration }\end{array}$ & 53 & 180 & 2.34 & 0.493 & & 3.39 & 0.78 & & 0.66 \\
\hline Reduced Harvest & 47 & 179 & 0.26 & 1.000 & & 3.33 & 0.77 & & 0.72 \\
\hline Disease Resistant Oysters & 57 & 182 & 3.15 & 0.363 & & 3.41 & 0.83 & & 0.70 \\
\hline Manage Water Flows & 48 & 178 & 4.68 & 0.191 & & 3.32 & 0.80 & & 0.65 \\
\hline Marine Protected Areas & 43 & $92^{\ddagger}$ & 3.42 & 0.335 & & & & & \\
\hline
\end{tabular}

${ }^{\dagger}$ Individual ecosystem services, causes of decline and initiatives were posed as separate questions, and responses were used to create a scale for each. For ecosystem services, two separate scales were calculated, and the scale with the highest $\alpha$

$\geq 0.70$ is shown.

Question was part of split-sample design.

$* P \leq 0.05, * * P \leq 0.01$.

respondents not dependent upon healthy fisheries. The majorcauses-of-decline scale included all potential stressors (Table 3; $\alpha$ $=0.75$ ). In Texas, water pollution was the only stressor perceived as a major cause of decline by at least $70 \%$ of individuals, but parasites and diseases, hurricanes, and overharvesting were considered major causes by at least $50 \%$ (Table 4). The environmental dependence of respondents did significantly affect perceptions of major stressors. The major-causes-of-decline scale for Texas included all potential stressors (Table 4; $\alpha=0.81$ ).
Perceived effectiveness and support of stewardship initiatives

In Alabama, we assessed the perceived effectiveness of five potential stewardship initiatives for maintaining healthy oyster reefs and oyster fisheries, and these involved increased fines for sewage spills, spawning sanctuaries, restoration, shorter harvest season, and stricter harvest limits. Stricter fines for sewage spills were most often chosen as the most effective option at $39 \%$, followed by spawning sanctuaries at 33\% and restoration at $20 \%$ (Table 2). Perceived effectiveness of stewardship initiatives was not significantly affected by the participants' environmental 
Table 4. Scale descriptives and results of Fisher's Exact Tests (FET) on environmental dependence for Texas.

\begin{tabular}{|c|c|c|c|c|c|c|c|c|c|}
\hline \multirow[b]{2}{*}{ Texas } & \multirow[b]{2}{*}{$\%$} & \multicolumn{3}{|c|}{$\begin{array}{c}\text { Environmental } \\
\text { Dependence }\end{array}$} & \multirow[b]{2}{*}{$\mathrm{n}$} & \multicolumn{4}{|c|}{$\begin{array}{c}\text { Scale } \\
\text { Descriptives }\end{array}$} \\
\hline & & $\mathrm{n}$ & FET & $\mathrm{P}$ & & Mean & $\mathrm{SD}$ & $\alpha$ & $\Delta \alpha$ \\
\hline \multicolumn{10}{|l|}{ Values \& Beliefs } \\
\hline Ecosystem Services ${ }^{\dagger}$ & $\begin{array}{c}\text { (Very } \\
\text { Important) }\end{array}$ & & & & 162 & & & 0.76 & \\
\hline Water Quality & 90 & 178 & 2.03 & 0.567 & & 2.92 & 0.27 & & 0.76 \\
\hline Shoreline Erosion & 78 & 179 & 6.01 & 0.096 & & 2.70 & 0.53 & & 0.73 \\
\hline Habitat and Refuge & 83 & $85^{\ddagger}$ & 1.82 & 0.639 & & 2.80 & 0.46 & & 0.70 \\
\hline Food and Culture & 78 & $89^{\ddagger}$ & 1.89 & 0.606 & & 2.73 & 0.57 & & 0.69 \\
\hline Fishing Industry Jobs & 84 & 178 & 1.12 & 0.792 & & 2.77 & 0.49 & & 0.72 \\
\hline Breeding Grounds & 82 & $92^{\ddagger}$ & 5.80 & 0.115 & & & & & \\
\hline Fish Foraging Grounds & 81 & $91^{\ddagger}$ & 5.57 & 0.106 & & & & & \\
\hline Fertilizer and Materials & 61 & 161 & 0.69 & 0.878 & & 2.59 & 0.63 & & 0.72 \\
\hline \multicolumn{10}{|l|}{ Problem Definition \& } \\
\hline \multicolumn{10}{|l|}{ Recognition } \\
\hline Current Condition & & 135 & 2.14 & 0.737 & & & & & \\
\hline Pretty Good or Better & 22 & & & & & & & & \\
\hline Poor or Failing & 30 & & & & & & & & \\
\hline Trajectory & & 136 & 2.19 & 0.718 & & & & & \\
\hline Increasing & 3 & & & & & & & & \\
\hline Decreasing & 74 & & & & & & & & \\
\hline Causes of Decline $\dagger$ & (Major Cause) & & & & 224 & & & 0.81 & \\
\hline Water pollution & 74 & 172 & 0.45 & 0.782 & & 2.66 & 0.60 & & 0.79 \\
\hline Hurricanes & 59 & 173 & 3.03 & 0.220 & & 2.51 & 0.66 & & 0.79 \\
\hline Overharvesting & 60 & 170 & 2.58 & 0.277 & & 2.49 & 0.66 & & 0.80 \\
\hline Parasites and diseases & 57 & 157 & 0.62 & 0.821 & & 2.48 & 0.65 & & 0.78 \\
\hline Shell dredging & 46 & 141 & 2.62 & 0.292 & & 2.36 & 0.69 & & 0.78 \\
\hline Increased salinity & 37 & 150 & 4.80 & 0.102 & & 2.23 & 0.73 & & 0.80 \\
\hline Climate change & 37 & 171 & 5.50 & 0.061 & & 2.19 & 0.73 & & 0.80 \\
\hline Freshwater inflows & 39 & 156 & 0.48 & 0.808 & & 2.27 & 0.68 & & 0.79 \\
\hline Predation & 22 & 169 & 4.74 & 0.087 & & 2.06 & 0.74 & & 0.82 \\
\hline \multicolumn{10}{|l|}{ Alternatives \& Initiatives } \\
\hline Support for Initiatives ${ }^{\dagger}$ & $\begin{array}{l}\text { (Strongly } \\
\text { Support) }\end{array}$ & & & & 340 & & & 0.81 & \\
\hline Spawning Sanctuaries & 61 & $91^{\ddagger}$ & 2.61 & 0.248 & & 3.46 & 0.80 & & 0.76 \\
\hline $\begin{array}{l}\text { Shell Planting / } \\
\text { Restoration }\end{array}$ & 53 & 177 & 3.39 & 0.318 & & 3.37 & 0.80 & & 0.70 \\
\hline Reduced Harvest & 48 & 180 & 13.80 & $0.002 * *$ & & 3.29 & 0.85 & & 0.77 \\
\hline Disease Resistant Oysters & 48 & 176 & 2.09 & 0.542 & & 3.24 & 0.93 & & 0.74 \\
\hline Manage Water Flows & 43 & 170 & 2.16 & 0.561 & & 3.15 & 0.93 & & 0.74 \\
\hline Marine Protected Areas & 43 & $87^{\ddagger}$ & 0.66 & 0.911 & & & & & \\
\hline
\end{tabular}

${ }^{\dagger}$ Individual ecosystem services, causes of decline, and initiatives were posed as separate questions, and responses were used to create a scale for each. For ecosystem services, two separate scales were calculated, and the scale with the highest $\alpha \geq 0.70$ is shown. ${ }^{\ddagger}$ Question was part of split-sample design.

$* P \leq 0.05, * * P \leq 0.01$.

dependence (Table 2). In Louisiana and Texas, participants were asked about their support of breeding of disease-resistant oysters, reef restoration and reconstruction, reduced harvest, spawning sanctuaries or MPAs, and management of river flows. In both states, spawning sanctuaries, breeding of disease-resistant oysters, and reef reconstruction were among the most strongly supported (Tables 3 and 4). MPAs and managing river flows were consistently among the least supported. In Texas, respondents not dependent upon healthy fisheries were more supportive of restrictions on harvest than those that were (Table 4). The effect of environmental dependence was not significant for any other initiative. The support-for-initiatives scale included all initiatives except MPAs in both Louisiana (Table 3; $\alpha=0.79$ ) and Texas (Table 4; $\alpha=0.81$ ).

We used regression analyses to identify explanatory variables for understanding the perceived effectiveness of initiatives in 
Table 5. Final regression models for examining stewardship support in each state. For Alabama, multinomial logistic regression was used on the categorical response variable regarding the perceived most effective initiative. For Louisiana and Texas, linear regression models were used on the overall initiative support scale.

\begin{tabular}{|c|c|c|c|c|c|c|}
\hline & \multicolumn{2}{|c|}{ Alabama } & \multicolumn{2}{|c|}{ Louisiana } & \multicolumn{2}{|c|}{ Texas } \\
\hline & $X^{2}$ & $\mathrm{P}$ & Coefficient & $\mathrm{P}$ & Coefficient & $\mathrm{P}$ \\
\hline \multicolumn{7}{|l|}{ Values \& Beliefs } \\
\hline Overall Environmental Health & 5.02 & 0.413 & $\mathrm{n} / \mathrm{a}$ & $\mathrm{n} / \mathrm{a}$ & $\mathrm{n} / \mathrm{a}$ & $\mathrm{n} / \mathrm{a}$ \\
\hline Ecosystem Services & $\mathrm{n} / \mathrm{a}$ & $\mathrm{n} / \mathrm{a}$ & 0.10 & 0.545 & 0.27 & 0.179 \\
\hline \multicolumn{7}{|l|}{ Problem Definition \& Recognition } \\
\hline Status or Condition & 17.85 & 0.120 & -0.09 & 0.605 & -0.41 & $0.043^{*}$ \\
\hline Trajectory & $\mathrm{n} / \mathrm{a}$ & $\mathrm{n} / \mathrm{a}$ & 0.09 & 0.569 & 0.34 & 0.095 \\
\hline Causes of Decline & 37.26 & $* * 0.001$ & 0.58 & $0.001 * *$ & 0.54 & $0.007 * *$ \\
\hline \multicolumn{7}{|l|}{ Demographics } \\
\hline Gender & 2.87 & 0.413 & 0.12 & 0.340 & -0.19 & 0.243 \\
\hline Race & 11.72 & 0.230 & 0.21 & 0.116 & 0.08 & 0.616 \\
\hline Education & 3.91 & 0.689 & 0.02 & 0.964 & -0.09 & 0.839 \\
\hline Income & 12.17 & 0.204 & -0.27 & 0.069 & -0.09 & 0.598 \\
\hline Environmental Dependence & 0.87 & 0.833 & -0.14 & 0.285 & 0.10 & 0.539 \\
\hline \multirow[t]{3}{*}{ Age } & 15.90 & 0.196 & 0.10 & 0.417 & 0.03 & 0.861 \\
\hline & 114.93 & $* * 0.004$ & & & & \\
\hline & \multicolumn{2}{|c|}{${ }^{\dagger} 0.17$} & \multicolumn{2}{|c|}{0.44} & \multicolumn{2}{|c|}{0.30} \\
\hline
\end{tabular}

Alabama or support for initiatives in Louisiana and Texas. Across all three states, we found that perspectives on initiatives were related to perceptions about the causes of decline. For Alabama, multinomial logistic regression indicated that perceptions of which stewardship initiative would be most effective were closely related to perceptions of which stressor was responsible for most harm (Table 5). The greatest variability appeared to be associated with stricter fines for sewage spills and spawning sanctuaries. Stricter sewage spill fines were perceived most positively by respondents who perceived poor water quality, pollution, or other stressors to cause the most harm, whereas those concerned with hurricanes and ineffective management were more in favor of sanctuaries and restoration (Fig. 3). In Louisiana and Texas, multiple linear regression analysis indicated that overall support for initiatives was positively associated with the major-causes-ofdecline scale (Table 5). We further explored this relationship by graphically comparing mean support for each initiative by individual stressor and among only respondents who perceived it to be a major cause of decline. In Louisiana, the greatest range of support appeared to be for MPAs, which were more supported when overharvesting was perceived as a major cause of decline (Fig. 4a). In Texas, support for MPAs again appeared to be the most context specific, but in this case, concern about overharvesting as a major cause still only contributed to moderate levels of support (Fig. 4b). Across both states, spawning sanctuaries and restoration were among the most consistent and highly supported initiatives (Fig. 4).

To further explore heterogeneity in support for restoration and spatial management, we used classification and regression tree analysis. In Alabama, restoration was perceived as the most effective option by $22 \%$ of all respondents and was perceived even more favorably among older, wealthier, and male respondents
Fig. 3. Perceived most effective initiative across respondents with differing views on the most damaging stressor for Alabama oysters.

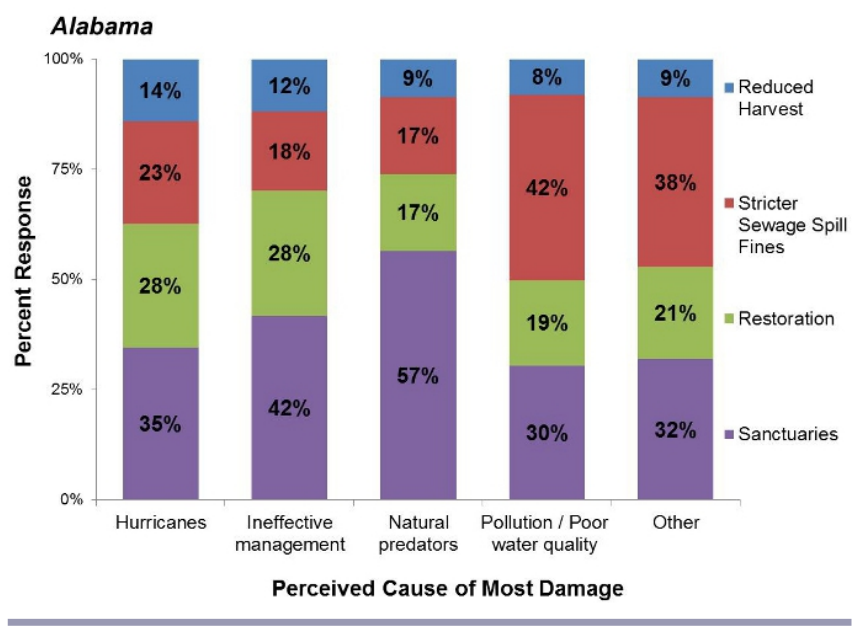

(Fig. 5a). Sanctuaries were perceived as the most effective initiative by $33 \%$ of all respondents and perceived most positively by individuals younger than age 40 (Fig. 5b). In Louisiana, 53\% of respondents were strongly supportive of restoration, which was more supported by white and other respondents than by black or African American, Hispanic, or Latino respondents (Fig. 6a). Among these groups, restoration was even more supported by respondents older than age 34. Sanctuaries were strongly supported by $58 \%$ of the public, with individuals older than age 44 or with an annual household income higher than $\$ 60,000$ more 
Fig. 4. Support of stewardship initiatives across each stressor perceived to be a major cause of decline for Louisiana (a) and Texas (b) oysters. All of the shown stressors and initiatives were asked as individual questions; therefore, individual survey participants may fall in multiple categories.

\section{a. Louisiana}

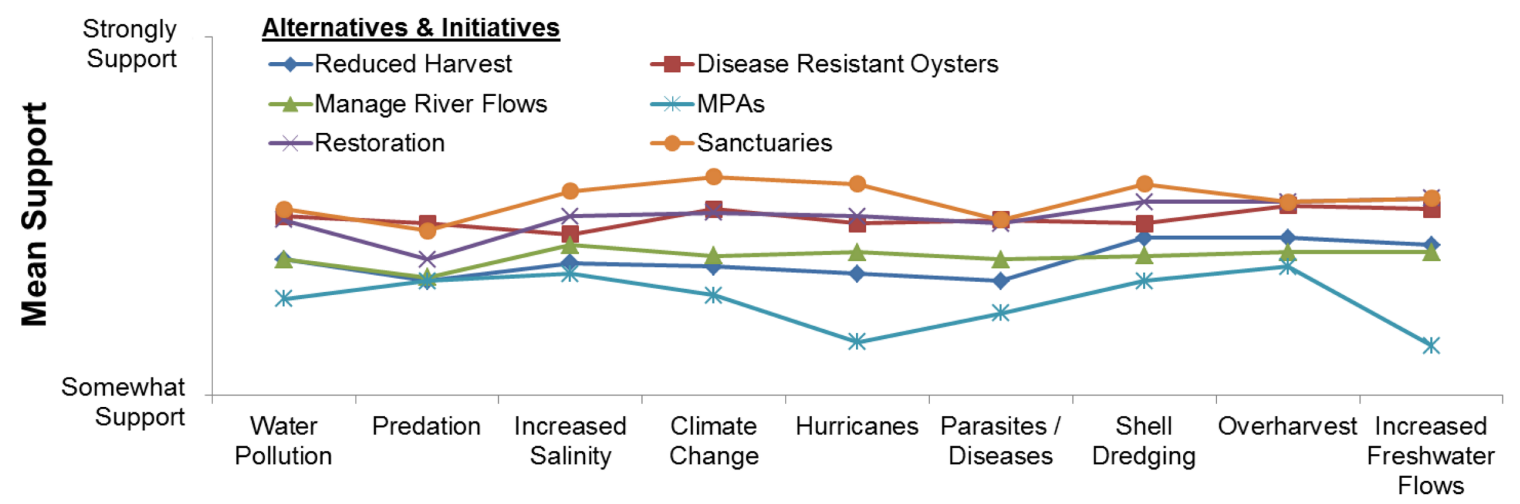

\section{b. Texas}

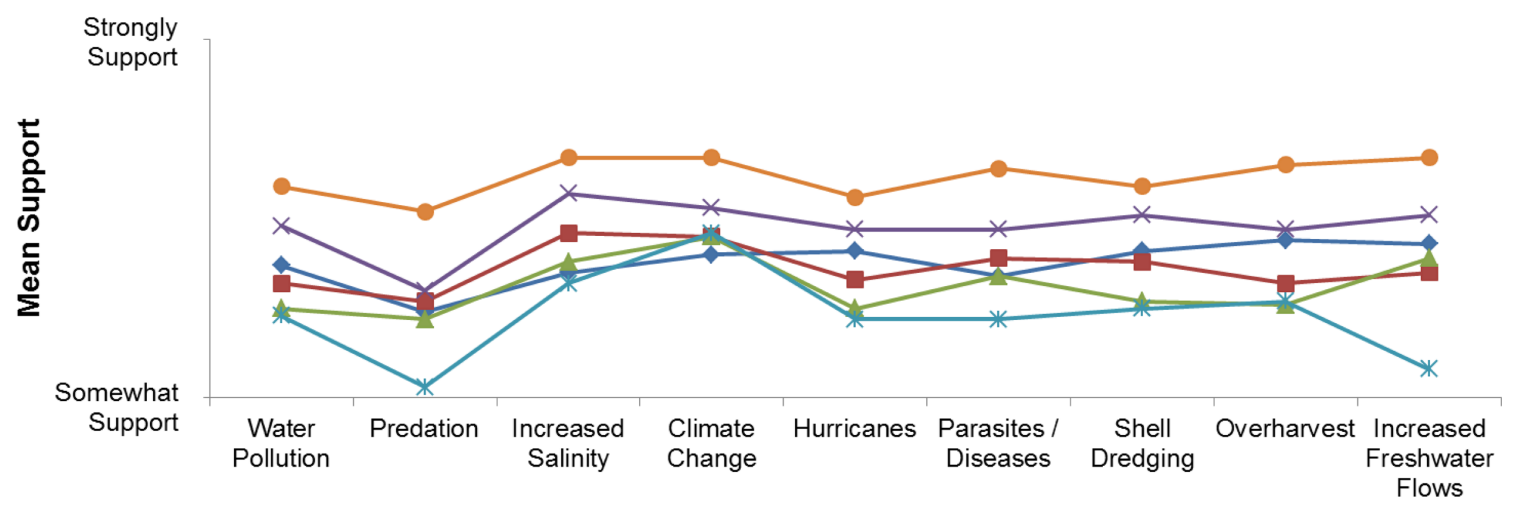

Stressor Perceived as "Major Cause of Decline"

supportive than younger, lower-income participants (Fig. 6b). MPAs were strongly supported by $43 \%$ of the public, and even more popular among highly educated, younger females (Fig. 6c). In Texas, restoration was again strongly supported by $53 \%$ of the public, with $65 \%$ of environmentally dependent respondents with at least some college education strongly supportive (Fig. 7a). Sanctuaries were strongly supported by $61 \%$ of the respondents, with even greater support from environmentally dependent individuals with formal higher education (Fig. 7b). MPAs were strongly supported by $43 \%$ of the public, with strong support most common among Hispanic or Latino and other nonwhite, black, or African American respondents (Fig. 7c). Among white and black or African American respondents, strong support for sanctuaries was most common among individuals 35 years old or younger with an annual household income of more than than $\$ 60,000$.

\section{DISCUSSION}

Accounting for and incorporating stakeholder values and perspectives remain common obstacles to successfully implementing conservation and ecosystem management initiatives (Biggs et al. 2011). This is especially true within the SES of oyster reefs and coastal societies, where heavy societal investment is often required to minimize the implicit trade-offs between harvest and ecosystem-services values. Our study focused on understanding how coastal societies value and perceive oyster reef ecosystem services, recognize and define causes of oyster population decline, and perceive and support alternatives and initiatives for enhancing sustainability. We found societal-level awareness of multiple ecosystem services, diminished population levels, and broad support for stewardship initiatives that promote both fisheries and environmental sustainability (Fig. 8). However, our results also identified knowledge gaps and perceptions that could bottleneck publicly supported stewardship opportunities and result in further declines in ecosystem services if major stressors are not counteracted.

An important aspect of assessing the sustainability of an SES involves thinking broadly about how social settings may influence the interactions and outcomes of the system (Dietz et al. 2003, Ostrom 2009). For exploited ecosystem engineers such as oyster reefs, this would likely require understanding how society and stakeholders value multiple ecosystem services, recognize natural and anthropogenic threats to sustainability, and prioritize the 
Fig. 5. Tree showing the most powerful predictors for explaining variability among individuals who perceived restoration (a) and spawning sanctuaries (b) as the most effective stewardship initiative in Alabama. The value shown within each oval is percent response for most effective, and separate branches within the tree indicate statistical differences at $\mathrm{P} \leq 0.05$.

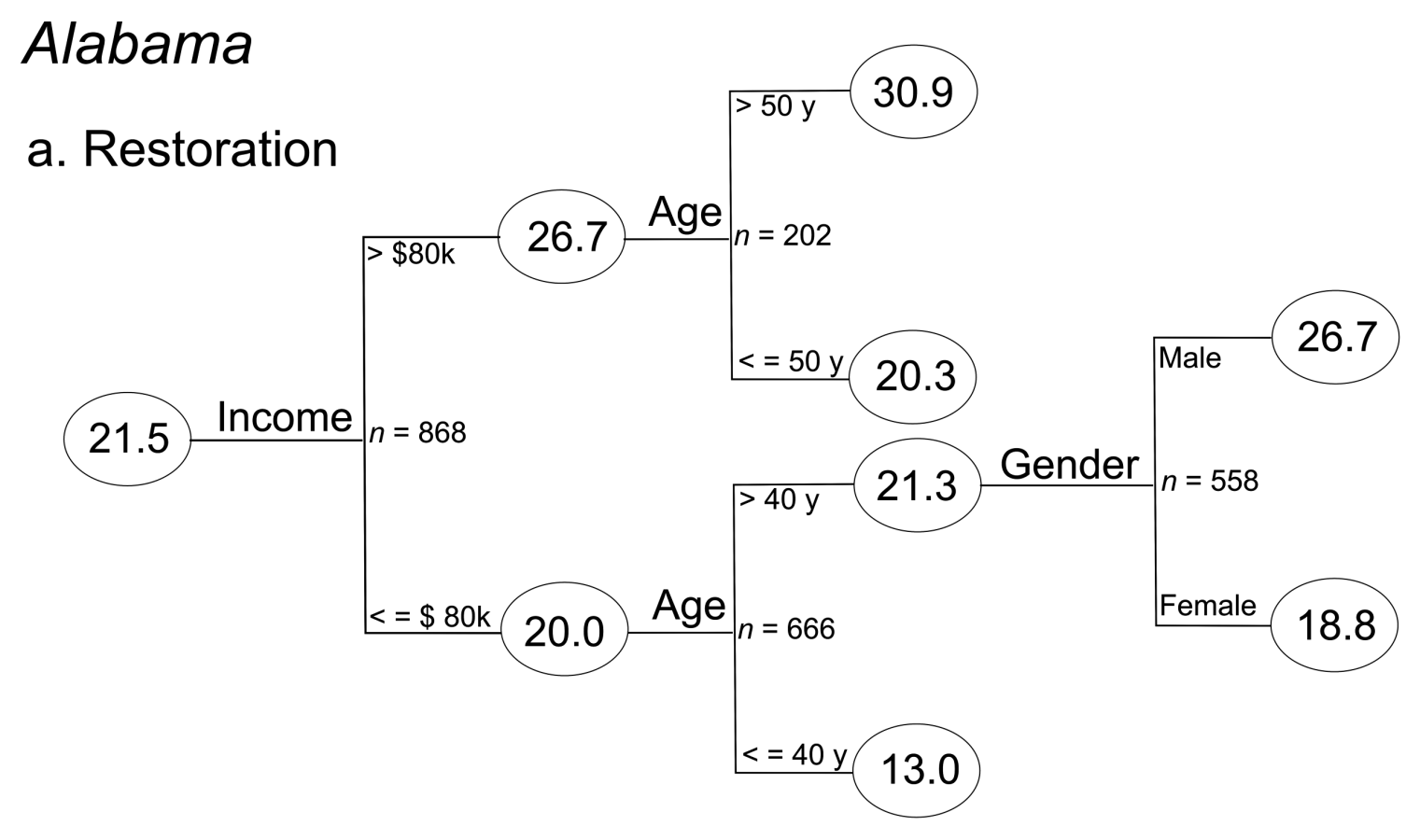

\section{b. Sanctuaries}

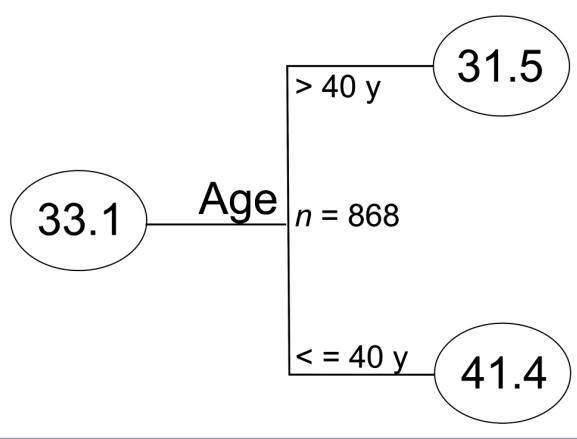

trade-offs among values and initiatives. In the past, governments and societies have often undervalued or failed to recognize the importance of natural habitats and the ecosystem services they provide until after they have been degraded or lost (Chambers et al. 2007, Daily et al. 2009). However, more recently, substantial attention has been paid to quantifying and ascribing economic values to goods and services provided by coastal habitats to promote better decision making (e.g., Brumbaugh and Toropova 2008, Barbier et al. 2011, Grabowski et al. 2012). Our study clearly shows that there is high public awareness of and appreciation for a range of oyster reef ecosystem services, which were recently estimated to have a value of between $\$ 5500$ and $\$ 99,000$ per hectare annually (Grabowski et al. 2012). Within the northern GOM, numerous ecological studies have documented the ecosystem services provided by oyster reefs, which include water filtration, shoreline stabilization, and habitat for diverse communities of fishes and invertebrates (e.g., Piazza et al. 2005, Stunz et al. 2010, Humphries et al. 2011, Scyphers et al. 2011, Beseres et al. 2013). We found that water filtration, habitat, and the buffering of shoreline erosion were widely recognized and valued by coastal society. However, oyster management strategies in the northern GOM and beyond have generally ignored or given only limited consideration to nonharvest ecosystem services as specific management objectives until recently. The results of our study, along with the valuations of oyster ecosystem services, point toward substantial societal and economic reasoning for developing management and stewardship strategies that consider services such as shoreline protection, habitat, and water filtration in addition to harvest values.

Our study also revealed that a high proportion of coastal residents recognize that oyster reefs have declined from a previously better condition. Across all three states, poor water quality or pollution 
Fig. 6. Tree showing the most powerful predictors for explaining variability among individuals who strongly support restoration (a), spawning sanctuaries (b), and MPAs as stewardship initiatives in Louisiana. The value shown within each oval is percent response for strongly support, and separate branches within the tree indicate statistical differences at $\mathrm{P} \leq 0.05$.

\section{Louisiana}

\section{a. Restoration}

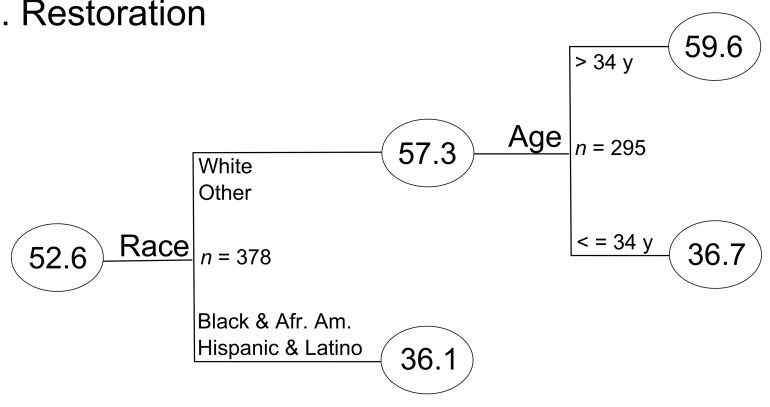

\section{b. Sanctuary}

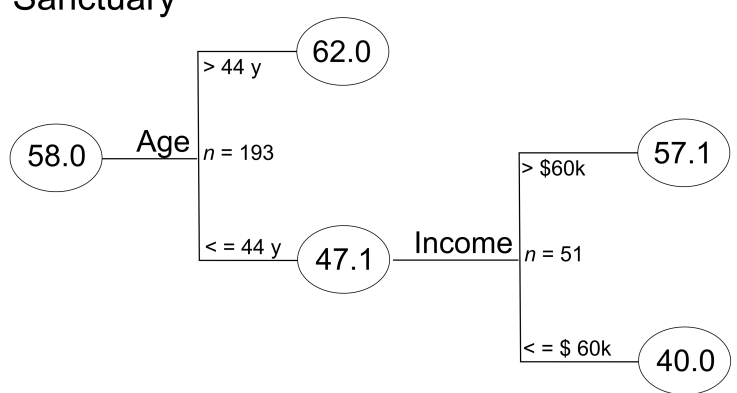

C. MPA

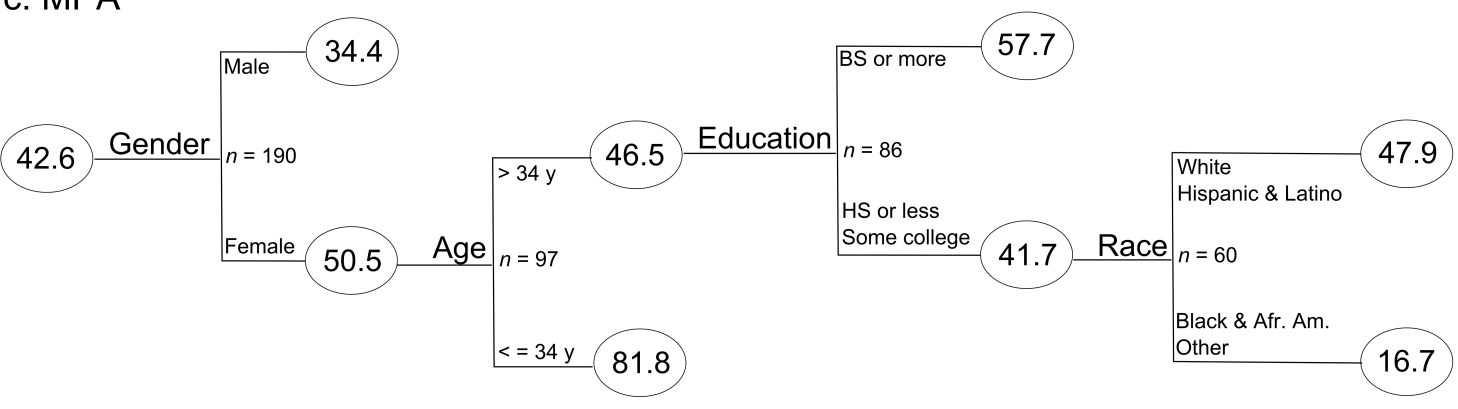

was perceived as most responsible for oyster decline, whereas only respondents in Texas believed that overharvesting or ineffective management has been a major cause of oyster decline. In Louisiana, the low concern about overharvesting may result from relatively consistent landings. Across the broader region, the relatively low concern about overharvesting may represent a scenario in which subtle long-term stressors were simply overshadowed by more recent, visible, and/or dramatic stressors such as hurricanes and oil spills. Among the most notable recent stressors was the 2010 explosion and sinking of the oil rig Deepwater Horizon, which released an estimated 4.4 million barrels of oil into the Gulf of Mexico (Crone and Tolstoy 2010). Because our Alabama survey was conducted six months after the incident, it is possible that this contributed to the common perception of poor water quality and pollution as the greatest cause of oyster decline. However, water pollution was also ranked first in Louisiana and Texas, and these surveys were conducted a year earlier in 2009. Considering that the western Gulf of Mexico is persistently affected by large-scale hypoxic events, often described as "dead zones," it is also likely that awareness of the detrimental impacts of agricultural and other nutrient pollution contributed to the high levels of concern.

The effects of hurricanes on oyster populations were also of great concern to respondents, although slightly less among those surveyed in Texas. All three states experienced a hurricane between 2008 and 2010, and the responses of Louisiana coastal residents may have been influenced by the destruction of Hurricane Katrina in 2005, which also involved the release of an estimated 8 to 9 million gallons of oil into coastal waters (Picou 2009). Strong storms can affect oyster reef condition by displacing 
Fig. 7. Tree showing the most powerful predictors for explaining variability among individuals who strongly support restoration (a), spawning sanctuaries (b), and MPAs as stewardship initiatives in Texas. The value shown within each oval is percent response for strongly support, and separate branches within the tree indicate statistical differences at $\mathrm{P} \leq 0.05$.

Texas
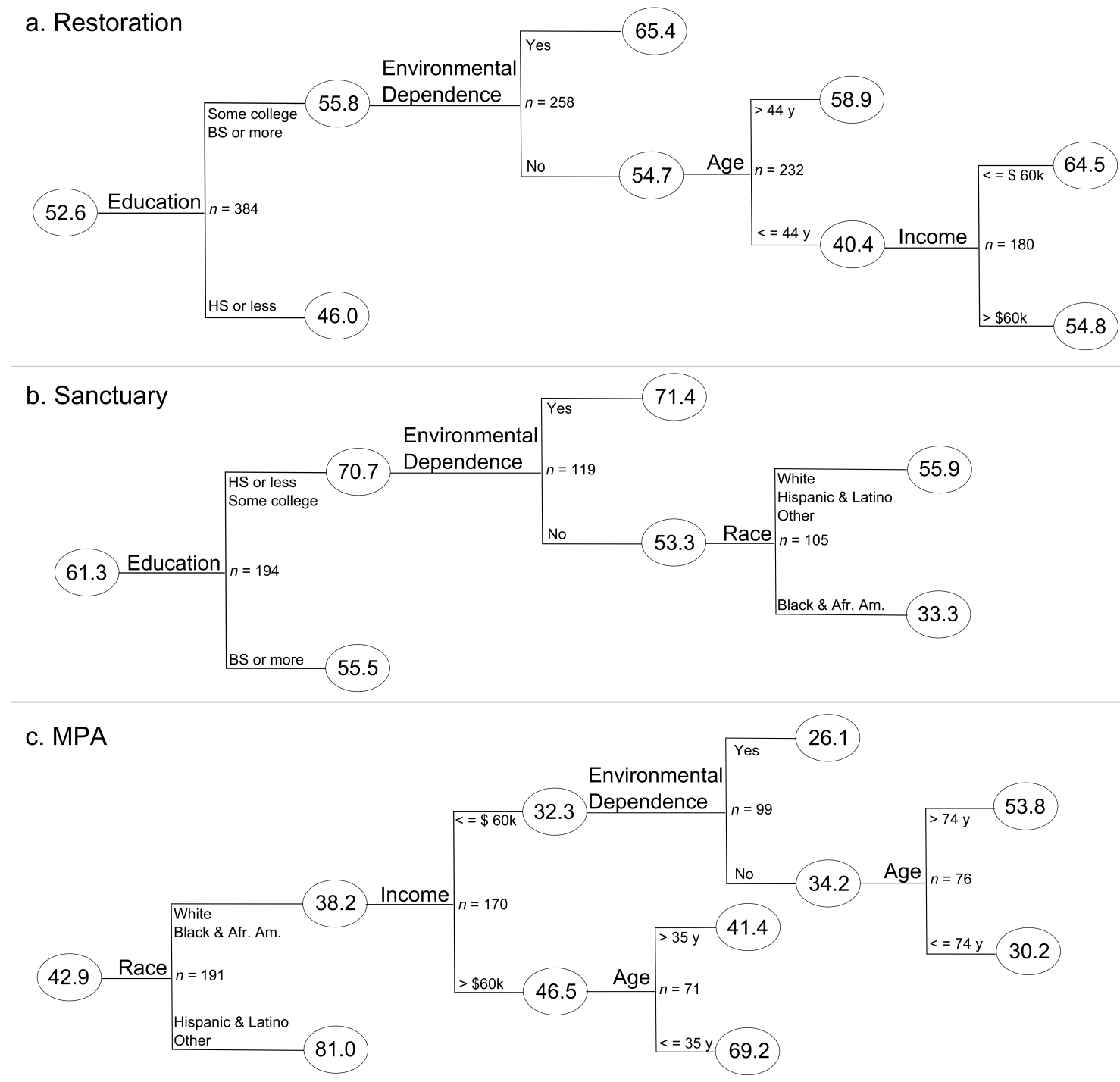

sediments and altering estuarine salinities, and the associated heavy rainfalls and attendant terrestrial runoff often trigger water-quality closures of oyster beds (Pine 2006). Such closures are often highly publicized to ensure public safety and therefore may also influence public perception of the overall health of reefs. Disease, poor water quality, and predation are all documented causes of oyster mortality in the northern GOM (e.g., Brown and Richardson 1988, La Peyre et al. 2003, Soniat et al. 2012b), but destructive and excessive harvesting has been proposed as the earliest and most dramatic cause of oyster reef decline (Kirby 2004). The societal-level recognition of oyster decline is a positive indicator of support for improving the sustainability of the SES. However, if excessive or destructive harvesting is a significant problem, our study suggests that aggressive educational outreach may be required to create a more informed and supportive public.

A central objective of our study was to understand the underlying drivers of support for management and stewardship initiatives, which can be influenced by numerous socioeconomic, cultural, and political factors and experiences (e.g., Cinner 2005, McClanahan et al. 2005, Gelcich et al. 2008, Scyphers et al. 2013). The most common and recently proposed initiatives for oysters have included reducing fishing pressure, increasing habitat availability, developing spawning sanctuaries and MPAs, increasing educational outreach, and improving management of freshwater and pollution inflows. Across the region, participants were generally more supportive of sanctuaries and restoration 
Fig. 8. Figure highlighting the wide recognition of numerous ecosystem services, broadly declined oyster reefs caused my multiple stressors, and identifying well-supported stewardship initiatives at state and regional scales. (Erratum: The original version of Figure 8 contained errors. A corrected version of the figure was published on 9 September 2015.)
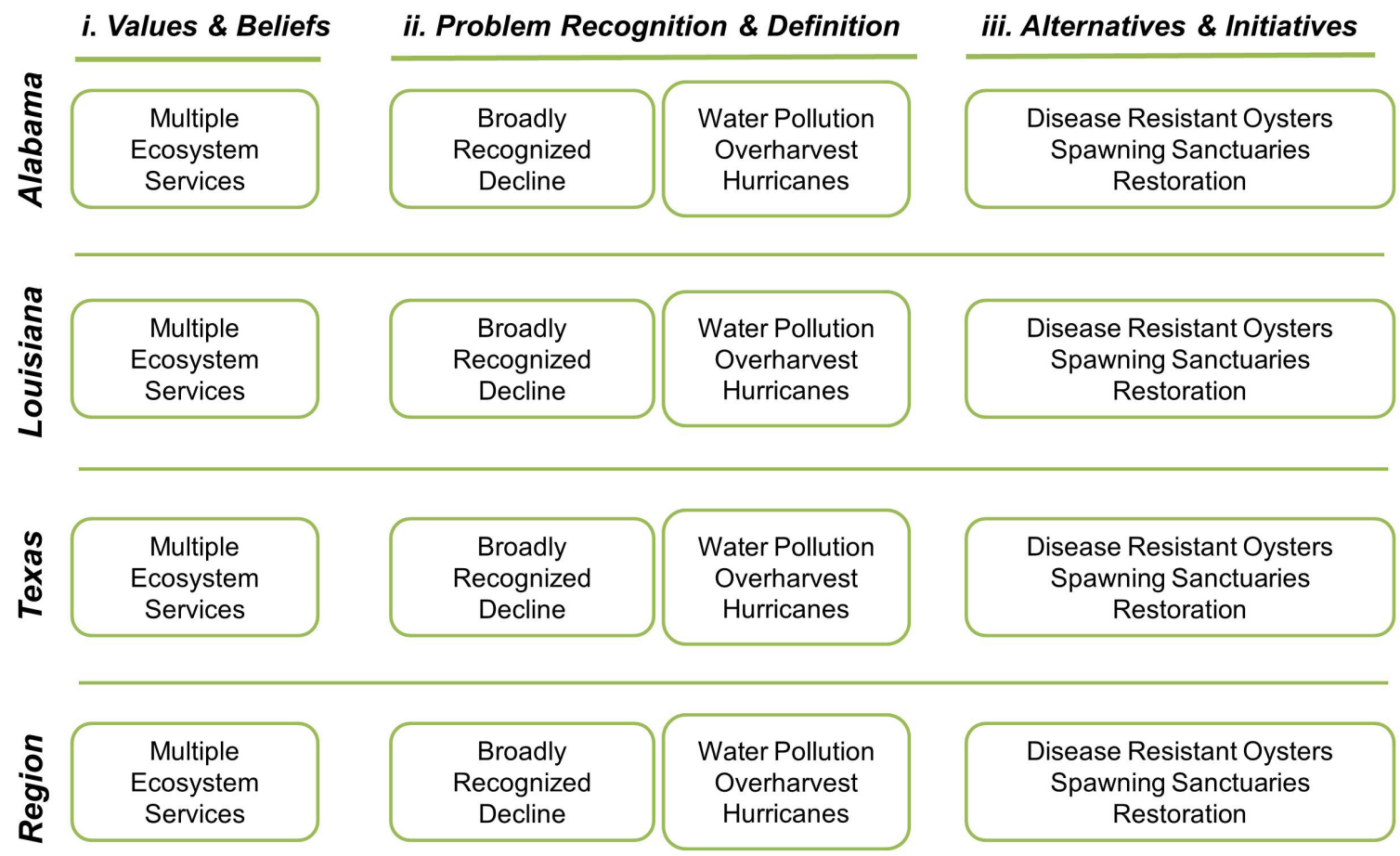

than initiatives to reduce or restrict harvest, which also supports the findings of previous studies of oyster industry stakeholders (La Peyre et al. 2012).

Along the U.S. Atlantic and Gulf coasts, large-scale reconstruction and enhancement of oyster reefs have been conducted with demonstrable success in meeting near-term restoration goals such as enhancing local recruitment of oyster larvae and stabilizing local oyster populations (Powers et al. 2009, Schulte et al. 2009); however, restoration efforts require substantial investment from state, federal, and nonprofit organizations or industry, and invested costs are likely not recovered unless harvest is restricted, enabling a suite of ecosystem services to be recovered (Grabowski et al. 2012). Furthermore, if ineffective management and overharvesting are contributing to poor oyster reef condition, some other proposed and publicly well-supported management initiatives could potentially exacerbate oyster reef decline rather than mitigating or reversing negative trends. For example, if stricter fines and enforcement resulted in less pollution and cleaner waters and additional areas were opened to oyster harvest, new exploitation could further degrade oyster reef habitats in areas currently off limits and protected by default from harvest. This point is made not to detract from the obvious incentives for improving the condition of coastal waters, but instead to caution against further declines in oyster ecosystem services if future harvests are ineffectively regulated.

Our study focused on a few commonly considered strategies for recovering oyster populations, and the likely reality is that effectively sustaining oyster reefs for harvest and ecosystem service values will require innovative approaches that combine or extend beyond those currently in place. For instance, oyster aquaculture could provide a possible avenue for supplying market demands and maintaining the harvest-related services while also reducing fishing pressure on wild populations. Although logistical and geopolitical factors may challenge the broad-scale expansion of near-shore aquaculture in the future, a nascent industry already exists in Alabama (Coddington 2012). Additionally, our study focused on environmental dependence within the broader social setting of the SES, and it is important to note that numerous other individual-level factors may influence sustainability or the outcome of any particular stewardship initiative (Picou and Marshall 2002, Scyphers et al. 2014). For instance, the interactions of resource users, other stakeholders, and governance systems are an integral component of the SES and were recently the focus of a similar study (La Peyre et al. 2012). The key findings of that study of oyster harvesters, shrimpers, environmental group members, and natural resource professionals were that restoring oyster reefs to enhance ecosystem services and initiating restrictions on harvest received much less support from oyster harvesters and shrimpers than from environmentalists and resource managers. Similar to the present study, La Peyre and colleagues also found that oyster harvesting was perceived as a lesser threat to oyster reefs. Collectively, historical relationships between stakeholders, resources, and governance systems may have long-lasting impacts on the sustainability of an SES (McClanahan and Cinner 2012, Scyphers et al. 2014), and the backstories of oysters and coastal communities vary greatly across the GOM and beyond (Dyer and Leard 1994). 
The decline of oysters resembles the decline of many other invertebrate fisheries that rapidly expanded and subsequently collapsed (Jackson et al. 2001, Kirby 2004, Anderson et al. 2011), but governmental and societal investments have led to successful and increasingly common recovery and restoration of oyster reefs (Powers et al. 2009, Schulte et al. 2009). The northern GOM is a region exhibiting lesser declines than the rest of the globe (Beck et al. 2011), and the three regions central to our study were estimated to have retained upwards of $50 \%$ of historical reef footprints (Zu Ermgassen et al. 2012). However, many bays in the region have experienced substantial declines in overall biomass of oysters ( $\mathrm{Zu}$ Ermgassen et al. 2012), and numerous stressors threaten longer-term sustainability. Our empirical findings suggest that resource managers and policy makers in the northern GOM have strong public support for several initiatives, e.g., sanctuaries, restoration, that could benefit oyster SES sustainability. However, garnering support for less popular initiatives such as restrictions on harvest may require educating the public and stakeholders on the costs, benefits, and trade-offs of ecosystem management strategies if excessive harvest is occurring. Collectively, the societal, economic, and biophysical complexities of northern GOM oyster SES illustrate the need and public support for developing more comprehensive management schemes for exploited ecosystem engineers.

Responses to this article can be read online at: http://www.ecologyandsociety.org/issues/responses. php/6835

\section{Acknowledgments:}

The survey instrument and methodology for the Alabama survey was approved by the University of South Alabama's Institutional Review Board (Protocol\#10-126, Exempt, 2 June 2010). Funding for the surveys was supported by the National Marine Fisheries Service Office of Habitat, the American Recovery and Reinvestment Act, the University of South Alabama's Oyster Restoration Program, and The Nature Conservancy. Steven Scyphers was supported by National Science Foundation grant OCE-1215825 during part of this work. We thank Fairbank, Maslin, Maullin, \& Associates and the polling centers at the University of South Alabama and the University of North Florida. We thankJ. Grabowski, L. Coen, K. Heck, P. Edwards, and J. Cinner for advice and comments that helped improve our manuscript. We are especially grateful to J. Will, P. Edwards, and K. Nicholls for their comments and advice on survey design, planning, and delivery. Figure 1 was created using MentalModeler software.

\section{LITERATURE CITED}

Adger, W. N. 2000. Social and ecological resilience: are they related? Progress in Human Geography 24(3):347-364. http://dx. doi.org/10.1191/030913200701540465

Agresti, A., and B. Finlay. 1997. Statistical methods for the social sciences. Third edition. Prentice Hall, Upper Saddle River, New Jersey, USA.

Anderson, S. C., J. M. Flemming, R. Watson, and H. K. Lotze. 2011. Rapid global expansion of invertebrate fisheries: trends, drivers and ecosystem effects. PloS One 6: e14735. http://dx.doi. org/10.1371/journal.pone.0014735

Bailey, C., and C. Pomeroy. 1996. Resource dependency and development options in coastal Southeast Asia. Society \& Natural Resources 9(2):191-199. http://dx.doi.org/10.1080/08941929609380964

Barbier, E. B., S. D. Hacker, C. Kennedy, E. W. Koch, A. C. Stier, and B. R. Silliman. 2011. The value of estuarine and coastal ecosystem services. Ecological Monographs 81(2):169-193. http:// dx.doi.org/10.1890/10-1510.1

Beck, M. W., R. D. Brumbaugh, L. Airoldi, A. Carranza, L. D. Coen, C. Crawford, O. Defeo, G. J. Edgar, B. Hancock, M. C. Kay, H. S. Lenihan, M. W. Luckenbach, C. L. Toropova, G. Zhang, and X. Guo. 2011. Oyster reefs at risk and recommendations for conservation, restoration, and management. BioScience 61(2):107-116. http://dx.doi.org/10.1525/bio.2011.61.2.5

Beck, M. W., T. D. Marsh, S. E. Reisewitz, and M. L. Bortman. 2004. New tools for marine conservation: the leasing and ownership of submerged lands. Conservation Biology 18 (5):1214-1223. http://dx.doi.org/10.1111/j.1523-1739.2004.00230. $\underline{\mathrm{X}}$

Beseres, P. J., D. Yoskowitz, H.-C. Kim, and P. A. Montagna. 2013. Role and value of nitrogen regulation provided by oysters (Crassostrea virginica) in the Mission-Aransas estuary, Texas, USA. PLoS ONE 8(6):e65314. http://dx.doi.org/10.1371/journal. pone. 0065314

Biggs, D., N. Abel, A. T. Knight, A. Leitch, A. Langston, and N. C. Ban. 2011. The implementation crisis in conservation planning: could "mental models" help? Conservation Letters 4(3):169-183. http://dx.doi.org/10.1111/j.1755-263X.2011.00170.x

Brown, K. M., and T. D. Richardson. 1988. Foraging ecology of the southern oyster drill Thais haemastoma (Gray): constraints on prey choice. Journal of Experimental Marine Biology and Ecology 114(2):123-141. http://dx.doi.org/10.1016/0022-0981(88) $\underline{90133-5}$

Brumbaugh, R. D., and C. Toropova. 2008. Economic valuation of ecosystem services: a new impetus for shellfish restoration? Basins and Coasts News 2(2):8-15.

Carranza, A., O. Defeo, M. Beck, and J. C. Castilla. 2009. Linking fisheries management and conservation in bioengineering species: the case of South American mussels (Mytilidae). Reviews in Fish Biology and Fisheries 19(3):349-366. http://dx.doi.org/10.1007/ $\underline{\text { s11160-009-9108-3 }}$

Chambers, J. Q., J. I. Fisher, H. Zeng, E. L. Chapman, D. B. Baker, and G. C. Hurtt. 2007. Hurricane Katrina's carbon footprint on U.S. gulf coast forests. Science 318(5853):1107. http://dx.doi. org/10.1126/science.1148913

Chapin, F. S. III, S. R. Carpenter, G. P. Kofinas, C. Folke, N. Abel, W. C. Clark, P. Olsson, D. M. Stafford Smith, B. Walker, O. R. Young, F. Berkes, R. Biggs, J. M. Grove, R. L. Naylor, E. Pinkerton, W. Steffen, and F. J. Swanson. 2009. Ecosystem stewardship: sustainability strategies for a rapidly changing planet. Trends in Ecology \& Evolution 25(4):241-249. http://dx. doi.org/10.1016/j.tree.2009.10.008 
Cinner, J. 2005. Socioeconomic factors influencing customary marine tenure in the Indo-Pacific. Ecology and Society 10(1): 36. [online] URL: http://www.ecologyandsociety.org/vol10/iss1/ art36/

Coddington, R. C. 2012. Evaluation of a mechanical grader for the improvement of the aquaculture production of the eastern oyster, Crassostrea virginica, in the Northern Gulf of Mexico. Dissertation. Auburn University, Auburn, Alabama, USA.

Coen, L. D., M. W. Luckenbach, and D. L. Breitburg. 1999. The role of oyster reefs as essential fish habitat: a review of current knowledge and some new perspectives. American Fisheries Society Symposium 22:438-454.

Coleman, F. C., and S. L. Williams. 2002. Overexploiting marine ecosystem engineers: potential consequences for biodiversity. Trends in Ecology \& Evolution 17(1):40-44. http://dx.doi. org/10.1016/S0169-5347(01)02330-8

Cronbach, L. J. 1951. Coefficient alpha and the internal structure of tests. Psychometrika 16(3):297-334. http://dx.doi.org/10.1007/ $\underline{\mathrm{BF} 02310555}$

Crone, T. J., and M. Tolstoy. 2010. Magnitude of the 2010 Gulf of Mexico oil leak. Science 330(6004):634. http://dx.doi. org/10.1126/science. 1195840

Daily, G. C., S. Polasky, J. Goldstein, P. M. Kareiva, H. A. Mooney, L. Pejchar, T. H. Ricketts, J. Salzman, and R. Shallenberger. 2009. Ecosystem services in decision making: time to deliver. Frontiers in Ecology and the Environment 7(1):21-28. http://dx.doi.org/10.1890/080025

Dietz, T., E. Ostrom, and P. C. Stern. 2003. The struggle to govern the commons. Science 302(5652):1907-1912. http://dx.doi. org/10.1126/science.1091015

Dugas, R. J., E. A. Joyce, and M. E. Berrigan. 1997. History and status of the oyster, Crassostrea virginica, and other molluscan fisheries of the U.S. gulf of Mexico. Pages 187-210 in C. L. MacKenzie, Jr., V. G. Burrell, Jr., A. Rosenfeld, and W. L. Hobart, editors. The history, present condition, and future of the molluscan fisheries of North and Central America and Europe. Volume 1, Atlantic and gulf coasts. NOAA technical report NMFS 127. U. S. Department of Commerce, Seattle, Washington, USA.

Dyer, C. L., and R. L. Leard. 1994. Folk management in the oyster fishery of the U.S. Gulf of Mexico. Pages 55-89 in C. L. Dyer and J. R. McGoodwin, editors. Folk management in the world's fisheries: lessons for modern fisheries management. University Press of Colorado, Niwot, Colorado, USA.

Gelcich, S., M. J. Kaiser, J. C. Castilla, and G. Edwards-Jones. 2008. Engagement in co-management of marine benthic resources influences environmental perceptions of artisanal fishers. Environmental Conservation 35(1):36-45. http://dx.doi. org/10.1017/S0376892908004475

Gill, D. A., and J. S. Picou. 2001. The day the water died: the Exxon Valdez disaster and indigenous culture. Pages 277-301 in S. Biel, editor. American disasters. New York University Press, New York, New York, USA.

Grabowski, J. H., R. D. Brumbaugh, R. F. Conrad, A. G. Keeler, J. J. Opaluch, C. H. Peterson, M. F. Piehler, S. P. Powers, and A.
R. Smyth. 2012. Economic valuation of ecosystem services provided by oyster reefs. BioScience 62(10):900-909. http://dx. doi. org/10.1525/bio.2012.62.10.10

Grabowski, J. H., A. R. Hughes, D. L. Kimbro, and M. A. Dolan. 2005. How habitat setting influences restored oyster reef communities. Ecology 86(7):1926-1935. http://dx.doi.org/10.1890/04-0690

Halpern, B. S., S. Walbridge, K. A. Selkoe, C. V. Kappel, F. Micheli, C. D’Agrosa, J. F. Bruno, K. S. Casey, C. Ebert, H. E. Fox, R. Fujita, D. Heinemann, H. S. Lenihan, E. M. P. Madin, M. T. Perry, E. R. Selig, M. Spalding, R. Steneck, and R. Watson. 2008. A global map of human impact on marine ecosystems. Science 319(5865):948-952. http://dx.doi.org/10.1126/science.1149345

Heberlein, T. A. 2012. Navigating environmental attitudes. Oxford University Press, New York, New York, USA. http://dx.doi. org/10.1111/j.1523-1739.2012.01892.x

Humphries, A. T., M. K. La Peyre, M. E. Kimball, and L. P. Rozas. 2011. Testing the effect of habitat structure and complexity on nekton assemblages using experimental oyster reefs. Journal of Experimental Marine Biology and Ecology 409(1):172-179. http:// dx.doi.org/10.1016/j.jembe.2011.08.017

IBM. 2012. IBM SPSS statistics for Windows. Version 21.0. IBM, Armonk, New York, USA.

Jackson, J. B. C. 2001. What was natural in the coastal oceans? Proceedings of the National Academy of Sciences of the United States of America 98(10):5411-5418. http://dx.doi.org/10.1073/ pnas.091092898

Jackson, J. B. C., M. X. Kirby, W. H. Berger, K. A. Bjorndal, L. W. Botsford, B. J. Bourque, R. H. Bradbury, R. Cooke, J. Erlandson, J. A. Estes, T. P. Hughes, S. Kidwell, C. B. Lange, H. S. Lenihan, J. M. Pandolfi, C. H. Peterson, R. S. Steneck, M. J. Tegner, and R. R. Warner. 2001. Historical overfishing and the recent collapse of coastal ecosystems. Science 293(5530):629-637. http://dx.doi.org/10.1126/science.1059199

Johnson, P., and D. Williams. 2013. Comparing ABS vs. landline RDD sampling frames on the phone mode. Survey Practice 3(3).

Jones, C. G., J. H. Lawton, and M. Shachak. 1994. Organisms as ecosystem engineers. Oikos 69(3):373-386. http://dx.doi. org/10.2307/3545850

Kirby, M. X. 2004. Fishing down the coast: historical expansion and collapse of oyster fisheries along continental margins. Proceedings of the National Academy of Sciences of the United States of America 101(35):13096-13099. http://dx.doi.org/10.1073/ pnas.0405150101

Kurlansky, M. 2007. The big oyster: history on the half shell. Random House Digital, New York, New York, USA.

La Peyre, M. K., A. D. Nickens, A. K. Volety, G. S. Tolley, and J. F. La Peyre. 2003. Environmental significance of freshets in reducing Perkinsus marinus infection in eastern oysters Crassostrea virginica: potential management applications. Marine Ecology Progress Series 248:165-176. http://dx.doi.org/10.3354/ $\underline{\text { meps } 248165}$

La Peyre, M. K., A. Nix, L. Laborde, and B. P. Piazza. 2012. Gauging state-level and user group views of oyster reef 
restoration activities in the northern Gulf of Mexico. Ocean \& Coastal Management 67:1-8. http://dx.doi.org/10.1016/j. ocecoaman.2012.06.001

Lenihan, H. S., and C. H. Peterson. 2004. Conserving oyster reef habitat by switching from dredging and tonging to diverharvesting. Fishery Bulletin 102(2):298-305.

Lotze, H. K., H. S. Lenihan, B. J. Bourque, R. H. Bradbury, R. G. Cooke, M. C. Kay, S. M. Kidwell, M. X. Kirby, C. H. Peterson, and J. B. C. Jackson. 2006. Depletion, degradation, and recovery potential of estuaries and coastal seas. Science 312 (5781):1806-1809. http://dx.doi.org/10.1126/science.1128035

McClanahan, T., J. Davies, and J. Maina. 2005. Factors influencing resource users and managers' perceptions towards marine protected area management in Kenya. Environmental Conservation 32(1):42-49. http://dx.doi.org/10.1017/S0376892904001791

McClanahan, T. R., and J. Cinner. 2012. Adapting to a changing environment: confronting the consequences of climate change. Oxford University Press, New York, New York, USA.

Menzel, S., and M. Buchecker. 2013. Does participatory planning foster the transformation toward more adaptive social-ecological systems? Ecology and Society 18(1): 13. http://dx.doi.org/10.5751/ ES-05154-180113

Meyer, D. L., E. C. Townsend, and G. W. Thayer. 1997. Stabilization and erosion control value of oyster cultch for intertidal marsh. Restoration Ecology 5(1):93-99. http://dx.doi. org/10.1046/j.1526-100X.1997.09710.X

Millennium Ecosystem Assessment. 2005. Ecosystems and human well-being: synthesis. Island Press, Washington, D.C., USA.

Naidoo, R., A. Balmford, R. Costanza, B. Fisher, R. E. Green, B. Lehner, T. R. Malcolm, and T. H. Ricketts. 2008. Global mapping of ecosystem services and conservation priorities. Proceedings of the National Academy of Sciences of the United States of America 105(28):9495-9500. http://dx.doi.org/10.1073/ pnas. 0707823105

National Marine Fisheries Service. 2009. Fishing communities of the United States 2006. NOAA technical memorandum NMFSF/SPO-98. National Marine Fisheries Service, Silver Spring, Maryland, USA.

Newell, R. I. E. 2004. Ecosystem influences of natural and cultivated populations of suspension-feeding bivalve molluscs: a review. Journal of Shellfish Research 23(1):51-61.

Ostrom, E. 2009. A general framework for analyzing sustainability of socio-ecological systems. Science 325 (5939):419-422. http://dx.doi.org/10.1126/science.1172133

Pandolfi, J. M., R. H. Bradbury, E. Sala, T. P. Hughes, K. A. Bjorndal, R. G. Cooke, D. McArdle, L. McClenachan, M. J. H. Newman, G. Paredes, R. R. Warner, and J. B. C. Jackson. 2003. Global trajectories of the long-term decline of coral reef ecoystems. Science 301(5635):955-958. http://dx.doi.org/10.1126/ science. 1085706

Peterson, C., J. H. Grabowski, and S. P. Powers. 2003. Estimated enhancement of fish production resulting from restoring oyster reef habitat: quantitative valuation. Marine Ecology Progress Series 264:249-264. http://dx.doi.org/10.3354/meps264249

Piazza, B. P., P. D. Banks, and M. K. La Peyre. 2005. The potential for created oyster shell reefs as a sustainable shoreline protection strategy in Louisiana. Restoration Ecology 13(3):499-506. http:// dx.doi.org/10.1111/j.1526-100X.2005.00062.X

Picou, J. S. 2009. Katrina as a Natech disaster: toxic contamination and long-term risks for residents of New Orleans. Journal of Applied Social Science 3(2):39-55. http://dx.doi. org/10.1177/193672440900300204

Picou, J. S., and B. K. Marshall. 2002. Contemporary conceptions of environmental risk: implications for resource management and policy. Sociological Practice 4(4):293-313. http://dx.doi. org/10.1023/A:1020898927326

Piehler, M. F., and A. R. Smyth. 2011. Habitat-specific distinctions in estuarine denitrification affect both ecosystem function and services. Ecosphere 2(1): art12. http://dx.doi. org/10.1890/ES10-00082.1

Pine, J. C. 2006. Hurricane Katrina and oil spills: impact on coastal and ocean environments. Oceanography 19(2):37-39. http://dx.doi.org/10.5670/oceanog.2006.61

Powers, S. P., C. H. Peterson, J. H. Grabowski, and H. S. Lenihan. 2009. Success of constructed oyster reefs in no-harvest sanctuaries: implications for restoration. Marine Ecology Progress Series 389:159-170. http://dx.doi.org/10.3354/meps08164

Rudel, T. 2013. Defensive environmentalists and the dynamics of global reform. Cambridge University Press, New York, New York, USA.

Schulte, D. M., R. P. Burke, and R. N. Lipcius. 2009. Unprecedented restoration of a native oyster metapopulation. Science 325(5944):1124-1128. http://dx.doi.org/10.1126/science.1176516

Schultz, P. W., V. V. Gouveia, L. D. Cameron, G. Tankha, P. Schmuck, and M. Franêk. 2005. Values and their relationship to evironmental concern and conservation behavior. Journal of Cross-Cultural Psychology 36(4):457-475. http://dx.doi. org/10.1177/0022022105275962

Scyphers, S. B., F. J. Fodrie, F. J. Hernandez, Jr., S. P. Powers, and R. L. Shipp. 2013. Venting and reef fish survival: perceptions and participation rates among recreational anglers in the Northern Gulf of Mexico. North American Journal of Fisheries Management 33(6):1071-1078. http://dx.doi.org/10.1080/027559$\underline{47.2013 .824932}$

Scyphers, S. B., J. S. Picou, and S. P. Powers. 2014. Participatory conservation of coastal habitats: the importance of understanding homeowner decision making to mitigate cascading shoreline degradation. Conservation Letters http://dx.doi. org/10.1111/conl.12114

Scyphers, S. B., S. P. Powers, K. L. Heck, Jr., and D. Byron. 2011. Oyster reefs as natural breakwaters mitigate shoreline loss and facilitate fisheries. PLoS ONE 6(8):e22396. http://dx.doi. org/10.1371/journal.pone.0022396

Soniat, T. M., J. M. Klinck, E. N. Powell, N. Cooper, M. Abdelguerfi, E. E. Hofmann, J. Dahal, S. Tu, J. Finigan, B. S. 
Eberline, J. F. La Peyre, M. K. La Peyre, and F. Qaddoura. $2012 a$. A shell-neutral modeling approach yields sustainable oyster harvest estimates: a retrospective analysis of the Louisiana state primary seed grounds. Journal of Shellfish Research 31 (4):1103-1112. http://dx.doi.org/10.2983/035.031.0421

Soniat, T. M., J. M. Klinck, E. N. Powell, and E. E. Hofmann. $2012 b$. Understanding the success and failure of oyster populations: periodicities of Perkinsus marinus, and oyster recruitment, mortality, and size. Journal of Shellfish Research 31 (3):635-646. http://dx.doi.org/10.2983/035.031.0307

Stedman, R. C., J. R. Parkins, and T. M. Beckley. 2004. Resource dependence and community well-being in rural Canada. Rural Sociology 69(2):213-234.

Stunz, G. W., T. J. Minello, and L. P. Rozas. 2010. Relative value of oyster reef as habitat for estuarine nekton in Galveston Bay, Texas. Marine Ecology Progress Series 406:147-159. http://dx.doi. org/10.3354/meps08556

Tidball, K., and R. Stedman. 2013. Positive dependency and virtuous cycles: from resource dependence to resilience in urban social-ecological systems. Ecological Economics 86:292-299. http://dx.doi.org/10.1016/j.ecolecon.2012.10.004

Vitousek, P. M., H. A. Mooney, J. Lubchenco, and J. M. Melillo. 1997. Human domination of Earth's ecosystems. Science 277 (325):494-499. http://dx.doi.org/10.1126/science.277.5325.494

Ward, W., and P. Weeks. 1994. Resource managers and resource users: field biologists and stewardship. Pages 91-113 in C. L. Dyer and J. R. McGoodwin, editors. Folk management in the world's fisheries. University Press of Colorado, Niwot, Colorado, USA.

Zander, K. K. 2013. Understanding public support for indigenous natural resource management in northern Australia. Ecology and Society 18(1): 11. http://dx.doi.org/10.5751/ES-05267-180111

Zu Ermgassen, P. S. E., M. D. Spalding, B. Blake, L. D. Coen, B. Dumbauld, S. Geiger, J. H. Grabowski, R. Grizzle, M. Luckenbach, K. McGraw, W. Rodney, J. L. Ruesink, S. P. Powers, and R. Brumbaugh. 2012. Historical ecology with real numbers: past and present extent and biomass of an imperilled estuarine habitat. Proceedings of the Royal Society B: Biological Sciences 279(1742):3393-3400. http://dx.doi.org/10.1098/rspb.2012.0313 
Appendix 1. Sample composition by county or parish (LA).

\begin{tabular}{|c|c|c|}
\hline Alabama & & \\
\hline & Baldwin & $49 \%$ \\
\hline & Mobile & $51 \%$ \\
\hline \multicolumn{3}{|l|}{ Louisiana } \\
\hline & Assumption & $1 \%$ \\
\hline & Calcasieu & $10 \%$ \\
\hline & Cameron & $0 \%$ \\
\hline & Iberia & $4 \%$ \\
\hline & Jefferson & $22 \%$ \\
\hline & Lafayette & $11 \%$ \\
\hline & Lafourche & $5 \%$ \\
\hline & Orleans & $16 \%$ \\
\hline & Plaquemines & $0 \%$ \\
\hline & St. Bernard & $1 \%$ \\
\hline & St. Charles & $3 \%$ \\
\hline & St. Martin & $2 \%$ \\
\hline & St. Mary & $3 \%$ \\
\hline & St. Tammany & $12 \%$ \\
\hline & Terrebonne & $6 \%$ \\
\hline & Vermillion & $4 \%$ \\
\hline \multicolumn{3}{|l|}{ Texas } \\
\hline & Aransas & $1 \%$ \\
\hline & Brazoria & $5 \%$ \\
\hline & Calhoun & $1 \%$ \\
\hline & Chambers & $1 \%$ \\
\hline & Fort Bend & $7 \%$ \\
\hline & Galveston & $5 \%$ \\
\hline & Harris & $70 \%$ \\
\hline & Jackson & $1 \%$ \\
\hline & Jefferson & $4 \%$ \\
\hline & Liberty & $1 \%$ \\
\hline & Matagorda & $1 \%$ \\
\hline & Orange & $1 \%$ \\
\hline & Refugio & $1 \%$ \\
\hline & San Patricio & $1 \%$ \\
\hline
\end{tabular}

